\title{
Genetics and functions of the retinoic acid pathway, with special emphasis on the eye
}

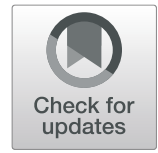

Brian Thompson ${ }^{1}$, Nicholas Katsanis ${ }^{2,3}$, Nicholas Apostolopoulos ${ }^{1}$, David C. Thompson ${ }^{4}$, Daniel W. Nebert ${ }^{5}$ and Vasilis Vasiliou ${ }^{1 *}$

\begin{abstract}
Retinoic acid (RA) is a potent morphogen required for embryonic development. RA is formed in a multistep process from vitamin A (retinol); RA acts in a paracrine fashion to shape the developing eye and is essential for normal optic vesicle and anterior segment formation. Perturbation in RA-signaling can result in severe ocular developmental diseasesincluding microphthalmia, anophthalmia, and coloboma. RA-signaling is also essential for embryonic development and life, as indicated by the significant consequences of mutations in genes involved in RA-signaling. The requirement of RAsignaling for normal development is further supported by the manifestation of severe pathologies in animal models of RA deficiency — such as ventral lens rotation, failure of optic cup formation, and embryonic and postnatal lethality. In this review, we summarize RA-signaling, recent advances in our understanding of this pathway in eye development, and the requirement of RA-signaling for embryonic development (e.g., organogenesis and limb bud development) and life.
\end{abstract}

Keywords: Retinoic Acid, Eye Development, gnomAD, ExAC

\section{Background}

For human health, the importance of retinol, also known as vitamin $\mathrm{A}$, has been known since ancient times, when the practice of squeezing liver juice into the eye was used as a treatment for night blindness [1]. The link between night blindness (nyctalopia) and nutrition was first described by Hippocrates during the 4th century $\mathrm{BC}$, when he recommended eating raw liver in combination with honey as a cure [2].

The idea that certain foods possessed curative properties was understood for much of human history. However, it was not until much later that a series of controlled experiments (i.e., human dietary supplementation and animal models during the early twentieth century) allowed scientists to investigate how removal of certain factors from the diet could cause debilitating illnesses and death [3-5]. Biochemical experiments in vertebrate models subsequently revealed that retinol was the active compound involved in cell growth and development, along with its precursors and metabolites [6].

\footnotetext{
* Correspondence: vasilis.vasiliou@yale.edu

${ }^{1}$ Department of Environmental Health Sciences, Yale School of Public Health, 60 College St, New Haven, CT 06520, USA

Full list of author information is available at the end of the article
}

The aldehyde derivative of retinol, 11-cis-retinal, is required for vision [reviewed in [7]]. All-trans-retinoic acid (ATRA), the acid derivative of retinol, is able to prevent developmental defects in vitamin A-deficient animals [8]. The demonstration that retinoic acid (RA) could not be converted back to retinol in vivo led to the conclusion that RA was a necessary nutrient involved in cell growth and development [9]. Ultimately, a set of compounds and their metabolites with biological functions similar to retinol were termed "retinoids" [10].

Although the chemical structures of retinoids were identified in the early 1900s, little was known about the mechanisms by which these small lipophilic molecules exerted their biological effects [6]. A short time later, studies performed in vitamin A-deficient rats revealed that retinol supplementation stimulated RNA synthesis in intestinal cells [11]. Biochemical studies subsequently identified serum, membrane, and cytosolic proteins that were essential for retinol transport, uptake, and metabolism [12]. Examples include retinol-binding protein 4 (RBP4), stimulated-by-retinoic-acid 6 (STRA6) membrane receptor, and the cellular retinol-binding protein (CRBP) family, also known as RBP1 and RBP2 [12].

Experiments carried out in chick and mouse embryos identified RA as the active metabolite of vitamin A that 
possessed the ability to regulate cellular differentiation and proliferation, as well as pattern formation during embryogenesis [reviewed in [13]]. At the molecular level, the action of RA is mediated by two distinct classes of proteins: (i) a family of nuclear receptors comprising RA receptors (RARs) and retinoid X receptors (RXRs) that regulate gene transcription in a ligand-dependent fashion and (ii) a family of cytosolic proteins called cellular retinoic acid-binding proteins (CRABP1 and CRABP2) which facilitate cellular RA uptake and nuclear transfer [14]. These studies provided a link between the chemical structure of retinoids and their biological action.

Although the developmental role of RA has been extensively studied in model organisms [reviewed in [13]], little is known about the exact role of RA in human development. Currently, almost all our molecular understanding about the pathogenesis of RA deficiency is based on either vertebrate animal knockout models (in which genes encoding proteins involved in RA synthesis or degradation are selectively inactivated) or experiments involving rodents fed diets deficient in vitamin A. Such studies have shown RA to be involved in early axial and central nervous system patterning, neurogenesis, regulation of limb bud development, and organogenesis [[3] and reviewed in [13, 14]]. To date, none of these studies has been systematically validated in humans due to ethical concerns and the difficulty of performing such clinical experiments. Nevertheless, based on observational studies in humans consuming vitamin A-deficient diets, it is well established that vitamin A is required in humans (even into adulthood) because it regulates fertility, maintains normal vision, inhibits neoplastic growth, and prevents neurodegenerative diseases [15].

With the recent publication of whole-exome sequencing (WES) data from $\approx 140,000$ individuals by the Genome Aggregation Database (gnomAD) [16], it is now possible to investigate genetic intolerance to protein-truncated variants (PTVs) in a large population, i.e., to detect genes that are essential for human development. In this review, we first provide an overview of canonical and non-canonical RA metabolism (i.e., synthesis and catabolism) and the mechanism of RA target gene regulation. We then provide an update on the role of RA-signaling in eye development in mouse and zebrafish and discuss the ocular diseases in humans who have mutations in genes involved in the RAsignaling pathway-such as microphthalmia, coloboma, and anophthalmia. Finally, we take advantage of population-level variation databases to identify which genes involved in the RA pathway display loss-of-function intolerance, thus indicating their requirement for human development and life.

\section{Main text}

Retinoic acid synthesis, catabolism, and gene regulation This section describes the components of the retinoic acid signaling pathway including cellular uptake of retinol, conversion of retinal to retinaldehyde, retinaldehyde oxidation to RA, RA degradation, and target gene activation (Fig. 1).

\section{Canonical pathway of RA synthesis}

Early studies revealed that retinoids could not be synthesized de novo in most animals [reviewed in [13]]. Hence, the major source of retinoids during embryonic and fetal development is through placental transfer of maternal retinol. Postnatally, retinoids are primarily derived from the dietary intake of (i) carotenoids (such as $\beta$-carotene) contained in plant pigments and (ii) retinyl esters from animal sources, such as fish-liver oils, eggs, milk, and butter. Following ingestion, retinyl esters are hydrolyzed to retinol by intestinal mucosal enzymes, whereas carotenoids are cleaved into retinal and subsequently reduced to retinol or oxidized to RA. Retinol homeostasis is tightly regulated. As such, much of the synthesized retinol is converted back into retinyl esters for storage in liver hepatocytes and stellate cells. When needed, these esters are cleaved and released into the bloodstream as retinol $[17,18]$. Upon release into the bloodstream, retinol is bound by retinol-binding protein 4 (RBP4).

Cells can take up the retinol-RBP4 complex via transmembrane receptor protein stimulated by retinoic acid 6 (STRA6), the product of the RA-inducible mouse gene Stra6 (or human STRA6 gene) [19]. The complex tissuespecific expression pattern of this gene during development influences which tissues are able to take up retinol [20]. Once inside the cell, two sequential reactions are required to transform retinol into retinaldehyde and RA (Fig. 1).

The first reaction is mediated by two classes of enzymes: (i) cytosolic alcohol dehydrogenases (ADHs) that belong to the medium-chain dehydrogenase/reductase family and/or (ii) microsomal retinol dehydrogenases (RDHs) that belong to the short-chain dehydrogenase/ reductase family [21]. Initial studies in mice indicated that this reaction was catalyzed by ADH7 in the embryo [22, 23]; however, tissue-specific RDH10 is now believed to play the most important role in RA synthesis during development because mice expressing mutant $R d h 10$ $\left(\mathrm{RDH} 10^{\text {trex }}\right.$ ) (that lacks the ability to convert retinol to retinal) display embryonic lethality [24]. Some degree of RA activity persists in mice expressing $\mathrm{RDH} 10^{\text {trex }}$ (revealed by limited RARE-lacZ reporter activity at E9.5), indicating that other enzymes (such as ADH7) are able to generate retinaldehyde, albeit at lower levels (that do not support embryonic development) [24]. In addition, transgenic suppression of ADH5 (an enzyme ubiquitously expressed in embryo and adult) or of tissuespecific ADH1 and ADH7 revealed that ADH enzymes may have a role in controlling removal of excess retinol, rather than participating in RA synthesis per se [25]. 


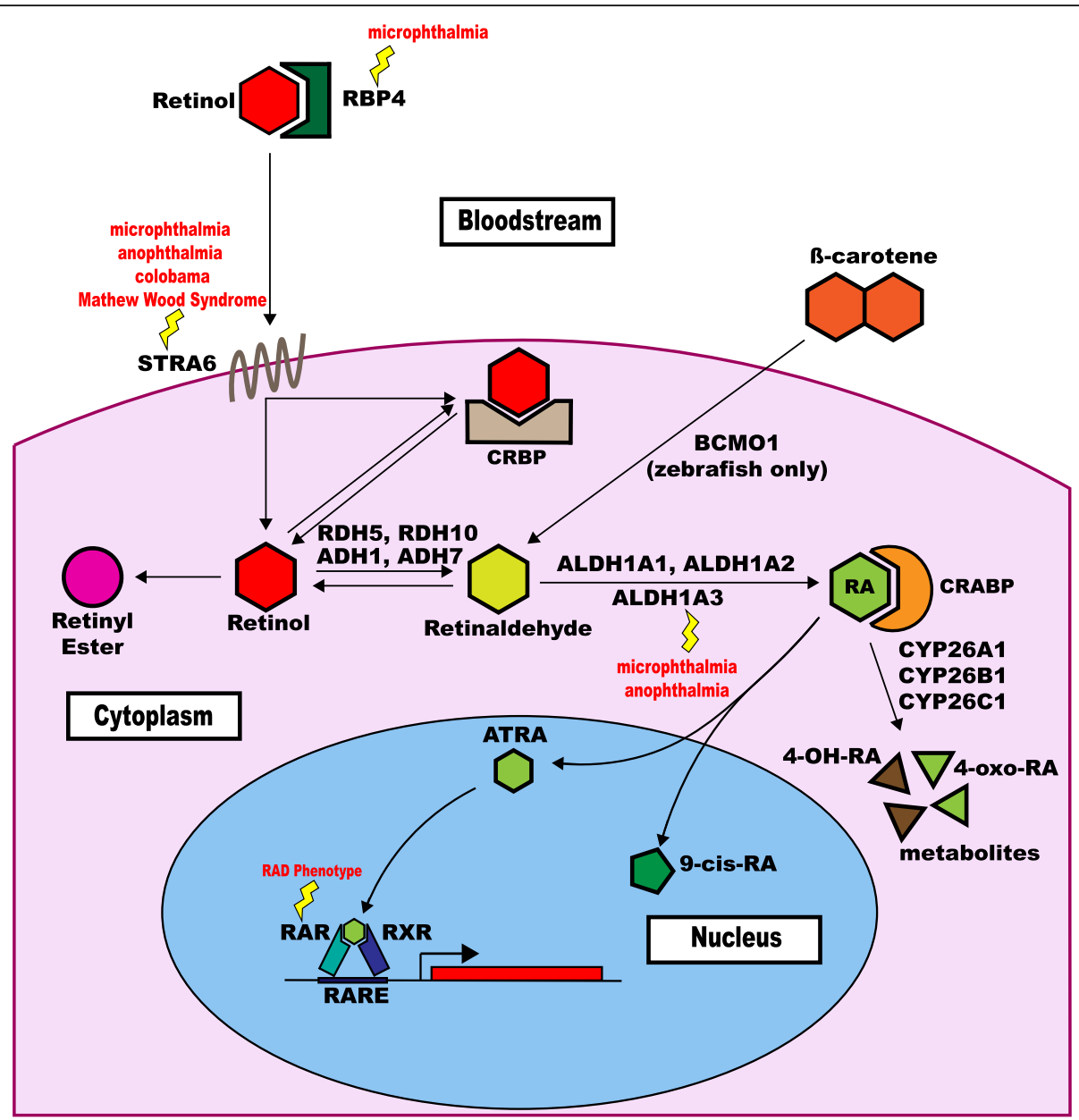

Fig. 1 Retinoic acid (RA)-signaling pathway. Extracellular binding and import of retinol, retinol conversion, oxidation of retinaldehyde to ATRA and/or 9-cis-RA, binding to RA receptors (RAR, RXR), degradation of RA to metabolites, and activation/repression of retinoic acid response elements (RARE). This diagram shows the activation (Arrow) of a target gene (Red box). Lightning bolts indicate genes with associated human eye development diseases. Abbreviations: RBP4, retinol-binding protein 4; STRA6, stimulated by retinoic acid 6; RDH5, retinol dehydrogenase 5; $\mathrm{RDH10}$, retinol dehydrogenase 10; $\mathrm{ADH1}$, alcohol dehydrogenase 1; $\mathrm{ADH7}$, alcohol dehydrogenase 7; $\mathrm{CRBP}$, cellular retinol-binding protein; ALDH1A1, aldehyde dehydrogenase 1 family member A1; ALDH1A2, aldehyde dehydrogenase 1 family member A2; ALDH1A3, aldehyde dehydrogenase 1 family member A3; CYP26A1, cytochrome P450 family 26 subfamily A member 1; CYP26B1, cytochrome P450 family 26 subfamily B member 1; CYP26C1, cytochrome P450 family 26 subfamily C member 1; ATRA, all-trans-retinoic acid; 9-cis-RA; RAR, retinoic acid receptor ; RXR, Retinoic $X$ Receptor; RARE, retinoic acid response elements.

The second reaction is oxidation of retinaldehyde to RA. This is catalyzed by three aldehyde dehydrogenases: ALDH1A1, ALDH1A2, and ALDH1A3 which are encoded (respectively) by Aldh1a1, Aldh1a2, and Aldh1a3 (respectively) in mice, or by $A L D H 1 A 1, A L D H 1 A 2$, and $A L D H 1 A 3$ in humans. Each ALDH displays a distinct expression pattern that closely correlates with RA activity and with the dynamics of RA-signaling. ALDH1A2 is responsible in the mouse for almost all RA production during early embryogenesis, i.e., until E8.5 [13]. During gastrulation, ALDH1A2 is expressed mainly along the primitive streak and in mesodermal cells in the posterior end of the embryo [26]. Later, ALDH1A2 is expressed in the somatic and lateral mesoderm, posterior heart tube, and rostral forebrain-and subsequently in prospective cervical and trunk levels during body axis extension [26]. Thereafter, ALDH1A3 is responsible for RA synthesis in the eye and olfactory system. ALDH1A1, thought to be partly redundant with ALDH1A3, has been demonstrated to act only during eye development $[27,28]$

\section{Alternative pathway of RA synthesis}

An alternative pathway for RA synthesis (elucidated in zebrafish) involves conversion of $\beta$-carotene to retinaldehyde by a $\beta$-carotene cleaving enzyme, $\beta$-carotene 15 , 15 -oxygenase 1 (BCO1) [29]. This pathway, believed to be an ancestral pathway from early chordates, is found mainly in marine fish in which retinaldehyde and 
carotenoids stored in the egg yolk are the main source of retinoids during development [29]. The mouse and human homolog, $\beta$-carotene 15,15'-oxygenase 1 (encoded by Bco1; $B C O 1$, previously known as $B C D O 1$ ), is expressed in retinal pigment epithelium (RPE) - as well as in kidney, intestine, liver, brain, stomach, and testis [30-32]. Its primary function is to generate retinaldehyde in photoreceptor cells and to supplement retinoid pools in other tissues [33].

In addition, a second $\beta$-carotene cleavage enzyme expressed in rabbits, $\beta$-carotene 9',10'-dioxygenase (encoded by the $\mathrm{BCO} 2$ gene), catalyzes the cleavage of $\beta$-carotene into $\beta$-apocarotenoic acid, which can be transformed into RA without any involvement of ALDHs [34]. Lastly, cell culture studies have revealed that CYP1B1, a member of the cytochrome P450 family, can catalyze conversion of retinol to retinaldehyde and RA. It remains to be seen if this enzyme meaningfully contributes to RA synthesis in mammals [35].

\section{RA catabolism}

Cellular levels of RA must be tightly regulated to prevent RA toxicity [reviewed in [36]]; this can occur through control of RA synthesis and RA catabolism (Fig. 1). RA is converted into polar derivatives (4-hydroxy-RA and 4oxo-RA) by the cytochrome P450 26 subfamily of enzymes, specifically CYP26A1, CYP26B1, and CYP26C1 [37-39]. Lethality occurs in CYP26A1, CYP26B1, and CYP26C1 null mouse models [40].

Although it was originally shown that the RA CYP26mediated polar derivative-4-oxo-RA-can interfere with embryonic development when delivered exogenously by binding to and activating RARs [41], more recent in vivo data suggest that CYP26-mediated catabolism is required for embryonic development because its removal of RA prevents inappropriate signaling in specific tissues [42]. The CYP26 enzymes display an expression pattern which matches that of the ALDHs during embryogenesis; their targeted disruption causes teratogenic effects similar to those seen in RA toxicity. In mice, Cyp26a1 and Cyp26c1 are the first genes to be expressed in the rostral-most embryonic epiblast, whereas Cyp26b1 is expressed in tail bud tissues and in the distal limb bud mesenchyme. Later in development, these enzymes display differential expression patterns in various developing organs, such as retina, dental epithelium, and inner ear [reviewed in [25]].

\section{RA gene activation or repression}

RA acts as an agonist of two nuclear receptor families that bind DNA and directly regulate transcription (Fig. 1). These families are (i) the RA receptors, i.e., retinoic acid receptor alpha (RARA), retinoic acid receptor beta (RARB) and retinoic acid receptor gamma (RARG), and (ii) the retinoid $\mathrm{X}$ receptors, i.e., retinoid $\mathrm{X}$ receptor alpha
(RXRA), retinoid $X$ receptor beta (RXRB), and retinoid $X$ receptor gamma (RXRG) [reviewed in [43]]. The RARs are highly conserved in vertebrates and are primarily activated by all-trans-RA (ATRA). By contrast, the RXRs are activated by 9-cis-RA, a stereoisomer of ATRA that is detected only when vitamin A is in excess. RXRs are thought to act as heterodimeric scaffolding proteins that facilitate binding of the RAR-RXR complex to DNA-complex demonstrates greater affinity for DNA than the RAR or RXR homodimers [44-46]. RARA, RXRA, and RXRB are widely expressed in tissues, suggesting that most tissues are potential targets of RA [reviewed by [47]]. Mouse knockout studies involving the RAR and RXR families have shown developmental abnormalities when two or more receptors are inactivated with the exception of RXRA-null mice which die in utero (vide infra), suggesting a degree of functional redundancy [25].

The DNA-binding sites for RARs and RXRs are known as retinoic acid response elements (RAREs) and contain direct repeats (DR) of 5'-AGGTCA-3' separated by one to five base pairs (termed DR1-DR5) [48, 49]. DRs (DR1-5) determine RA-activated RAR-RXR complex target gene expression. For example, DR5-containing genes display transcriptional activation, whereas DR1-containing genes display transcriptional repression [50]. So far, a wide variety of the RAR- and RXR-regulated genes have been shown to influence many cellular processes-e.g., the cellular uptake of RA (Crbp1/2 and Crabp1/2), RA catabolism (Cyp26a1), RA nuclear receptor beta (Rarb), mammalian embryonic pattern formation through the homeobox (Hox) family (Hoxa1, Hoxb1, Hoxb4, and Hoxd4), and organ growth/development (Pitx2, Drd2, Gad67, Fgf8, and Pdx1) [51-53].

\section{The retinoic acid pathway regulates eye development}

RA-signaling in mammalian eye development has been previously reviewed [54]. As such, we will focus on ocular developmental diseases associated with perturbed RAsignaling.

The process of eye development is largely conserved among chordates-including zebrafish, mice, and humans $[55,56]$. Mouse eye development begins at E8.0, at which time the optic vesicle forms on the cephalic neural folds [57]. The optic vesicle then begins to migrate towards the surface ectoderm until, at E9.0, the two ectodermal layers come into contact and begin to thicken. This contact initiates activation of a cascade of transcription factors (e.g., SIX3 and PAX6) [reviewed in [58]] and signaling pathways [e.g., BMP and RA (reviewed in [59]].

The optic vesicle then invaginates into the optic cup, and the surface ectoderm subsequently invaginates to form the lens placode. As the lens placode continues to invaginate, asymmetric cell growth then leads to formation of the lens pit, with the ultimate formation of the lens vesicle by E11. Epithelial cells located at the anterior 
portion of the lens vesicle maintain their epithelial identity and proliferative nature, whereas epithelial cells at the posterior lens vesicle differentiate into fiber cells and ultimately become primary lens fiber cells. The inner layer of the optic vesicle then becomes the neuroretina, while the outer layer becomes the RPE [60].

From mouse neuroretina, several neuronal subtypes (i.e., retinal ganglion cells, amacrine cells, horizontal cells, bipolar cells, photoreceptor cells) and Müller cells begin forming at E11. Corneal development begins when the lens stalk connecting the lens vesicle to the surface ectoderm is severed. The resulting space is rapidly filled by invading cells from perinuclear mesenchyme. Mesenchymal cells nearest the lens vesicle then form the corneal endothelium, while cells farthest from the lens vesicle form the corneal epithelium. Cells located between these two layers form the corneal stroma from which corneal keratocytes differentiate.

Corneal development is maintained by a constant influx of cells from the periocular mesenchyme (POM). Lens formation continues, with secondary fiber differentiation in the mouse beginning at the lens equator at E13.5-E14.5 (secondary fiber cell differentiation occurs throughout adulthood). Anterior segment development is completed by the anterior edge of the optic cup (which forms the epithelium of the iris and ciliary body), and migrating cells from the POM form stroma of the iris and ciliary body. Lastly, the trabecular meshwork is formed from migrating mesenchymal cells. Eye morphogenesis is largely conserved in mouse, zebrafish, and humans, but the process in zebrafish occurs in a much shorter time frame [56, 61].

Studies in animal models have revealed a requirement for RA-signaling in normal eye development. Beginning in the mid-twentieth century, research highlighted the importance of dietary vitamin A in maintaining rodent eye development $[3,62]$. Rats born to mothers maintained on a vitamin A-deficient diet displayed a multitude of ocular defects-including retina infolding, coloboma, microphthalmia, and anophthalmia (a syndrome ultimately termed vitamin A deficiency) - that could be rescued by vitamin A supplementation during embryonic development [3, 62]. However, the time of supplementation was critical, in that supplementation before E13.0 could rescue the ocular phenotypes whereas supplementation after E13.0 could not completely rescue eye development [3]. These studies demonstrated that vitamin A (and ultimately RA-signaling) is required for specific events in eye development, i.e., optic cup formation, anterior segment formation.

As noted, RA-signaling is modulated by several enzymes and dependent on RARs and RXRs (Fig. 1). Therefore, an alteration in any one of these proteins may perturb RA-signaling and affect normal eye development. Animal models used to investigate the RA-signaling pathway will be discussed in the order that the proteins appear within the pathway-starting with RBP4 and finishing with RARs and RXRs (Fig. 1).

In zebrafish, decreased stra6 (e.g., by morpholino knockdown) causes reduced eye size, despite the formation of all retinal layers [63]. In mouse, RDH10 was identified as essential for normal eye development [24]. RDH10deficient mice lack the cornea and ventral half of the retina and exhibit hypoplastic lenses. RDH10-depleted zebrafish display a mild RA loss of function phenotype [64], perhaps due to their ability to produce retinaldehyde through bcox [29]. A morpholino-mediated inhibition of $b c o x$ results in microphthalmic zebrafish with a diminished size of the ventral prospective retina tissue [29].

In mice, ALDHs are differentially required at various stages of eye development. ALDH1A2 is only expressed in the murine eye between E8.5 and E9.5 and is required for optic cup formation (Fig. 2a) [65]. In contrast, ALDH1A1 and ALDH1A3 are respectively expressed in dorsal and ventral retina from E10.5 onwards [27] (Fig. 2b). Aldh1a1-null mice exhibit no developmental ocular phenotype, likely due to compensation in RA-signaling by ALDH1A3 [27, 28]. Aldh1a3-null mice display developmental ocular phenotypes-resulting as ventral rotation of the lens, persistence of the primary vitreous, and thickening of the ventral POM $[27,66]$. Aldh1a1/Aldh1a3-null mice display all of the same phenotypes as Aldh1a3-null mice, but with greater severity; this would suggest that some of the loss of RA-signaling induced by the genetic ablation of Aldh1a3 is compensated by Aldh1a1 [27]. RA influences mammalian ocular development in a paracrine fashion; RA produced in the retina by ALDH1A1 and ALDH1A3 is secreted and acts on cells in the POM where it regulates expression of genes important for apoptosis and corneal morphogenesis and cell specification-Eya2 and Pitx2, respectively (Fig. 2b) [27, 67, 68].

Disruption in RA-signaling permits overgrowth of POM cells, which adversely affects normal anterior segment development [27, 28]. Ectopic lens expression of CRABP1 results in lenses with impaired secondary fiber cell differentiation (i.e., failure to lose nuclei) and a flattening of the anterior side of the fiber cells [69]. ATRA binds to and activates the RXR/RAR complex, which enables activation or repression of RARES (Fig. 1). Compound Rar gene deletions (for example, the deletion of both Rara and Rarb) result in aberrant ocular developmental phenotypes-including microphthalmia, coloboma, lens abnormalities, and retinal dysplasia and degeneration [70, 71].

Compound Rxra, Rxra/Rarg, and Rxra/Rara null mice all show ocular developmental abnormalities-including ventral rotation of the lens, thicker corneas, shorter ventral retinae, and coloboma [72]. Involvement of RA- 

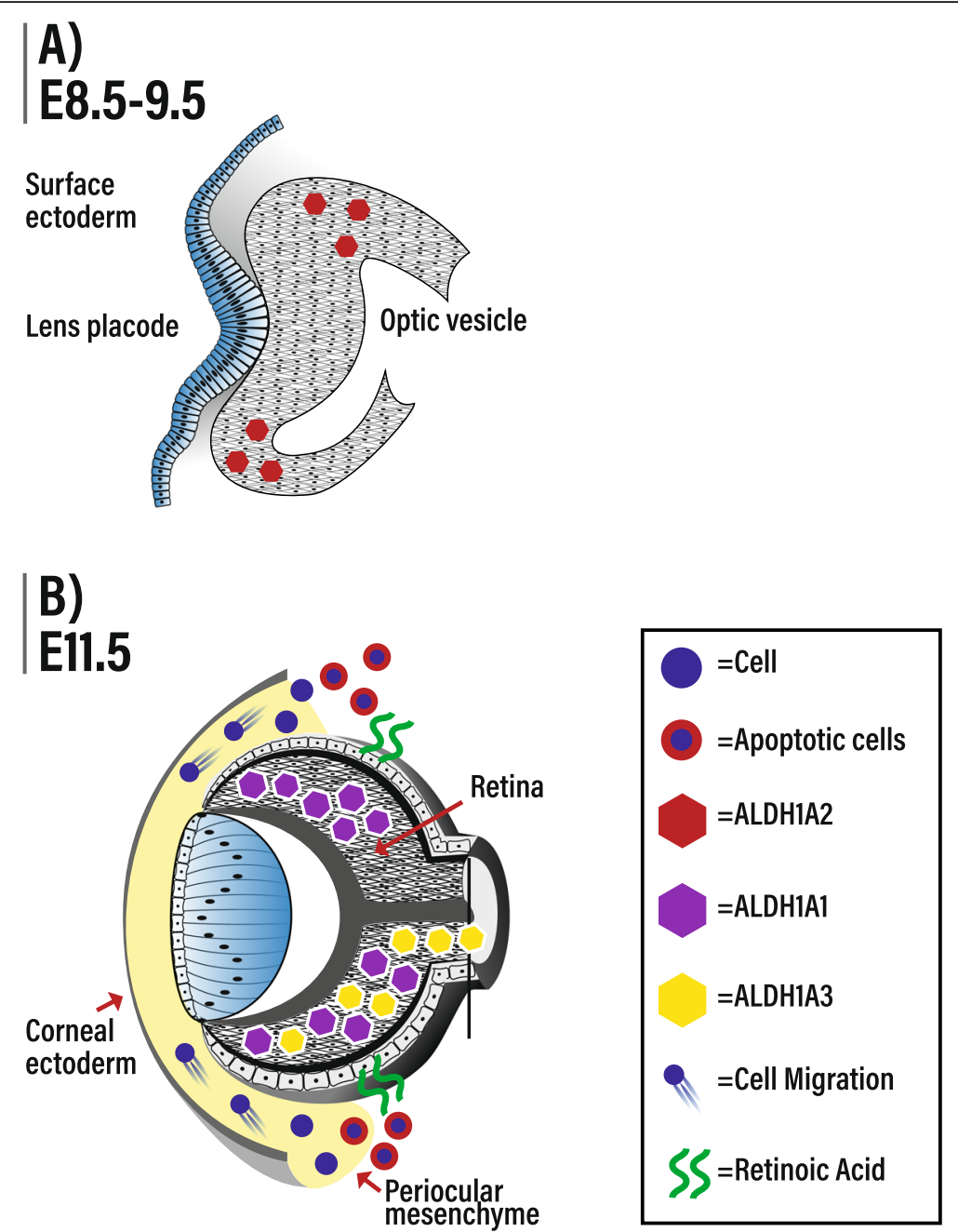

Fig. 2 The retinoic acid (RA)-signaling pathway and eye development. Key events in mouse eye development that are regulated by RA-signaling are shown. a Between E8.5 and E9.5, ALDH1A2 is expressed in the optic vesicle and is required for optic cup formation [65]. b Starting at E10.5, RA produced by ALDH1A1 and ALDH1A3 within the developing retina diffuses (shown by green arrows) into periocular mesenchyme (POM) where it activates RARBs/RARGs on POM cells to induce cell apoptosis and thus control the migration of POM cells to the anterior eye. This diagram represents conditions at E11.5 [inspired by [27]. Abbreviations: ALDH1A1, aldehyde dehydrogenase 1 family member A1; ALDH1A2, aldehyde dehydrogenase 1 family member A2; ALDH1A3, aldehyde dehydrogenase 1 family member A3; E, embryonic day

signaling in maintenance of POM cellular proliferation was confirmed by the conditional deletion of Rara, Rarb, and Rarg in neural crest cells; these knockout animals have impaired ocular development phenotypes similar to the previously described ALDH-deficient mice [68]. Collectively, these animal models have provided compelling evidence in support of an important role for RAsignaling in ocular development.

Mutations in genes involved in RA-signaling in humans are associated with developmental diseases-including the ocular developmental diseases, such as microphthalmia, anophthalmia, and coloboma (collectively called MAC disease), and Mathew-Wood Syndrome (Fig. 1). Linkage analysis and whole-exome sequencing have identified mutations in RBP4 in patients with MAC disease [73, 74]. Dominant-negative mutations in RBP4 increase RBP4 affinity for STRA6; this nonproductive occupation of STRA6 hinders delivery of vitamin $\mathrm{A}$ to the fetus. Maternal inheritance of $R B P 4$ mutations and a lack of maternal dietary retinoids predispose the fetus to MAC disease [73]. Mutations in STRA6 are associated with both syndromal (MathewWood Syndrome) and non-syndromal MAC disease [75-78]. A double-nucleotide polymorphism that causes a nonsynonymous change from glycine to lysine in a highly conserved region of the STRA6 protein was identified in MAC patients; this mutation almost completely abolishes cellular uptake of vitamin A [75].

Homozygous nonsense mutations, missense, and splice-site mutations in $A L D H 1 A 3$ are associated with 
microphthalmia [79-81]. Co-transfection of wild-type and mutated human $A L D H 1 A 3$ (c.265C $>\mathrm{T}$ and c.1477G $>\mathrm{C}$ ) revealed that the mutated ALDH1A3 protein is likely unstable and subject to proteasomal degradation [79]. Mutations in $R A R B$ have been identified in patients with syndromic MAC [i.e., pulmonary hypoplasia/agenesis, diaphragmatic hernia/eventration, anophthalmia/microphthalmia, and cardiac defect (PDAC)] [82, 83]. Evaluation of these mutations have indicated that both gain-of-function and dominant-negative mutations within $R A R B$ can cause PDAC syndrome [82]. A recent report identified a de novo mutation in RARA in a coloboma patient which is hypothesized to impair the interaction between RA and RARA [84].

It is clear that RA-signaling is similarly important for zebrafish, mouse, and human eye development. Given that it is unethical to investigate the role of RA-signaling in human eye development in a manner similar to that in animal models, it is currently unknown exactly how RA-signaling might impact human eye development. However, the conserved nature of RA-signaling and eye development across chordates suggests that RAsignaling is also very likely to act in a paracrine fashion to regulate eye development in humans.

\section{Deleterious clinical variations in the RA pathway}

The ExAC database (comprising whole-exome sequencing of more than 60,000 individuals) was published in 2016 [85]; it was recently expanded to include $\sim 140,000$ individuals [16]. Using this resource, it is now possible to gain insights into the necessity of various components of the RA pathway in humans and to explore the existence of nodes in the pathway that are of potential importance.

A gene with a high pLI score [85] would suggest that individuals who inherit loss-of-function (LOF) mutations in that gene will inherit a survival disadvantage. Analysis of pLI scores of genes involved in the RA-signaling pathway (Table 1) reveals that certain genes in this pathway are crucial for human embryogenesis and life-data that are consistent with mouse studies (Table 2). The RAsignaling pathway is essential for life, with $30 \%$ of RA-signaling pathway genes being categorized as LOF-intolerant. This is in striking contrast to $17 \%$ of all known genes being categorized as LOF-intolerant [85]. Several of the LOF-intolerant RA-signaling pathway genes have no known associated human disease, i.e., $R D H 10, R X R A, R X R B$ (Table 1); this would be predicted given the severe embryonic lethality observed in transgenic mouse models in which these three genes have been knocked out (Table 2).

A total of eight RA-signaling pathway genes [85] have markedly high pLI scores (pLI > 0.9), i.e., $A L D H 1 A 1$, CYP26B1, RARA, RARB, RARG, RXRA, RXRB, and $R D H 10$ (Table 1). These genes are therefore essential for life, e.g., DNA-binding functions and crucial for morphogenesis [156, 157].

pLI predictions and animal models are in agreement for one gene in particular-ALDH1A2. Humans are LOF-tolerant $(\mathrm{pLI}=0.36)($ Table 1$)$ and Aldh1a2 heterozygous null mice are viable. This highlights an important feature of pLI scores; they predict the probability of haploinsufficiency intolerance [158]. However, it is important to note that Aldh1a2-null mice experience embryonic lethality by E10.5 (Table 2) [111].

Despite the high level of conservation in the RA-signaling pathway between humans and mice, discrepancies in the extent of indispensability of RA-signaling pathway genes exist. $A L D H 1 A 1$ is intolerant of LOF mutations (pLI = 0.95) in humans (Table 1) whereas Aldh1a1 is dispensible in mice [27]. This may be related to loss of Aldh1a1 being compensated in mice by Aldh1a7-which is an Aldh1a1 gene duplication found in rodents but not in humans [159].

In mice, Cyp26b1 deletion is lethal immediately after birth [123, 124], whereas humans with CYP26B1 mutations can live to adulthood [96]. Cyp26a1-null mice experience embryonic lethality (Table 2), while human CYP26A1 is LOF-tolerant $(\mathrm{pLI}=0)$ (Table 1$)$. Differences between mouse [160] and human [161] CYP26A1 tissue expression may explain the differential requirements for life. For example, human MAP2-positive neurons in the human dentate gyrus express CYP26A1, whereas rat and mouse MAP2-positive neurons do not [162]. Further, human MAP2-positive neurons express ALDH1A2 along with CYP26A1, suggesting that RA acts in an autocrine fashion in these cells, as opposed to the paracrine fashion found in rodents. This may explain the differences in the requirement for life. Differences between mouse and human underscores the need for caution when generalizing the requirement for life of RA-signaling pathway genes across chordates. Despite this, mice still hold great utility as an experimental model when investigating the minutiae of the RA-signaling pathway.

Differences between animal models and humans can be further explained by incomplete penetrance in human-possibly due to differences in mutation type, variations in gene expression, epigenetic changes, age, sex, or copy number variations [163]. Often, experimental models used for investigation of the RA-signaling pathway rely on transgenic mice in which a pathway gene is completely ablated. This situation may not be representative of humans in whom gene mutations commonly result in lowered gene activity rather than zero expression. In addition, important differences during development in the patterns of expression of many genes and their pathways exist between mouse and human [164-166]. As was highlighted above, differences in the timing and/or location of RA-signaling pathway genes result in vast differences in this critical pathway-e.g., 


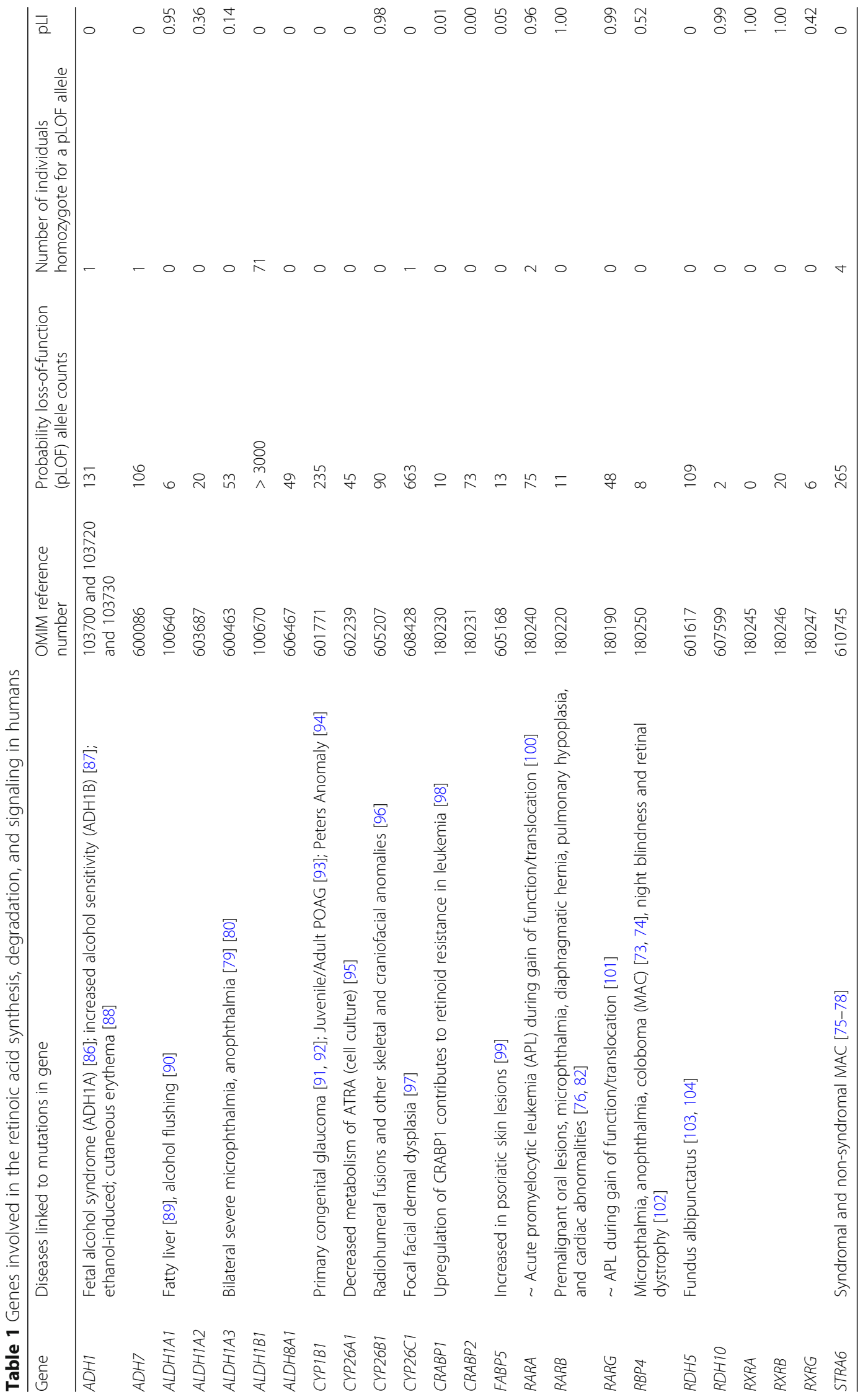


Table 2 Mouse phenotypes for genes involved in the retinoic acid synthesis, degradation, and signaling

\begin{tabular}{|c|c|c|c|}
\hline Gene & Synonyms & MGl identification number & Mouse knockout phenotypes (homozygous null mutations) \\
\hline Adh1 & & 87921 & $\begin{array}{l}\text { Impaired metabolism of (and sensitivity to) ethanol and } \\
\text { retinol [105-107] }\end{array}$ \\
\hline Adh7 & $\mathrm{ADH} 4$ & 87926 & $\begin{array}{l}\text { Defective ethanol clearance and reduced metabolism of } \\
\text { retinal to RA [105] }\end{array}$ \\
\hline Aldhial & RALDH1 & 1353450 & $\begin{array}{l}\text { Increased energy dissipation, insulin resistance, diet-induced } \\
\text { obesity resistance [108], significantly reduced ability to } \\
\text { convert retinol to retinoic acid in the liver [109] }\end{array}$ \\
\hline Aldh1a2 & RALDH2 & 107928 & $\begin{array}{l}\text { Devoid of retinoic acid, die by E10.5 with impaired } \\
\text { hindbrain development, failure to turn, lack of limb buds, } \\
\text { heart abnormalities, reduced otocysts and a truncated } \\
\text { frontonasal region [110-114] }\end{array}$ \\
\hline Aldhia3 & RALDH3 & 1861722 & $\begin{array}{l}\text { Neonatal death [115], persistent hyperplastic primary } \\
\text { vitreous, thick neural retina and no vitreum [28], choanal } \\
\text { atresia, ethmoturbinal hypoplasia, ventral lens rotation, } \\
\text { short ventral retina, and no Harderian gland [66] }\end{array}$ \\
\hline Aldh1b1 & ALDHX & 1919785 & $\begin{array}{l}\text { Increased fasting circulating glucose levels and decreased } \\
\text { blood acetaldehyde clearance [116], defects in beta cell } \\
\text { development and functionality, glucose intolerance, age- } \\
\text { dependent hyperglycemia, and insulin resistance [117] }\end{array}$ \\
\hline Aldh8a1 & ALDH12 or RALDH4 & 2653900 & None Found \\
\hline Cyp1b1 & & 88590 & $\begin{array}{l}\text { Protected from the acute bone marrow cytotoxic and } \\
\text { preleukemic effects of DMBA [118], show a decreased } \\
\text { incidence of DMBA-induced lymphomas [119], ocular } \\
\text { drainage structure abnormalities ( POAG) [120] }\end{array}$ \\
\hline Cyp26a1 & & 1096359 & $\begin{array}{l}\text { Mid-late gestation lethal and exhibit spina bifida, caudal } \\
\text { agenesis, and abnormalities of the kidneys, urogenital } \\
\text { tract, hindgut, cervical vertebrae, and rostral hindbrain } \\
{[121,122] \text {, rescued by partial Aldh1a2 deletion [42] }}\end{array}$ \\
\hline Cyp26b1 & & 2176159 & $\begin{array}{l}\text { Lethal immediately after birth exhibiting respiratory distress } \\
\text { [123], limb morphogenesis and proximal-distal patterning is } \\
\text { disrupted in homozygous null fetuses [123, 124], abnormal } \\
\text { spermatogenesis/oogenesis [125], arrested hair follicle } \\
\text { development [126] }\end{array}$ \\
\hline
\end{tabular}

Cyp26c1

Crabp 1

Crabp2

Fabp5

Rara

Rarb

Rarg

Rbp 1

Rbp2
CRBPI

97876

CRBPII

97877

2679699

88490

97856

97858

NR1B3 97858

97877
Viable, exhibit normal CNS development with no apparent anatomical defects [127]

Phenotypically normal and fertile [128]

Postaxial polydactyly [129]

Impaired skin barrier function [130], resistance to dietinduced obesity (decreased adipose tissue and improved glucose tolerance) [131], and impaired cognitive function $[132,133]$

High neonatal mortality due to maternal cannibalization, failure to thrive, and excess mortality during the postnatal period, male survivors exhibit testicular degeneration [134-136]

Reduced growth [137], locomotion abnormalities [138]

Stunted growth, homeotic transformations of the rostral axial skeleton and tracheal cartilage, Harderian gland agenesis, high postnatal mortality, and male sterility $[135,139]$, splenomegaly, and myeloproliferative disease, abnormal granulocytes [140]

Increased adiposity, increased PPAR-gamma target gene expression [141], increased Rpb2 and Crabp2, elevated pancreatic RA [142], increased susceptibility to a diet deficient in vitamin A [143]

Pups of homozygous dams fed a marginal retinol diet show increased neonatal lethality due to inadequate retinal transport to the fetus, abnormal retinol level and vitamin absorption [144] 
Table 2 Mouse phenotypes for genes involved in the retinoic acid synthesis, degradation, and signaling (Continued)

\begin{tabular}{|c|c|c|c|}
\hline Gene & Synonyms & MGl identification number & Mouse knockout phenotypes (homozygous null mutations) \\
\hline Rbp4 & & 97879 & $\begin{array}{l}\text { Impaired retinal function in first month of life [145], insulin } \\
\text { sensitivity [146] }\end{array}$ \\
\hline Rdh5 & & 1201412 & $\begin{array}{l}\text { Impaired dark adaptation and at high bleaching levels, } \\
\text { large increase in 11-cis-retinyl ester concentration [147] }\end{array}$ \\
\hline Rdh10 & & 1924238 & $\begin{array}{l}\text { Mid-gestational lethality, reduced RA-signaling and abnormal } \\
\text { limb, craniofacial, somite and cardiac morphology including } \\
\text { microphthalmia [24] and dorsal pancreas agenesis [148] }\end{array}$ \\
\hline Rxra & NR2B1 & 98214 & $\begin{array}{l}\text { Multiple organ defects and die of cardiac failure by E14.5, } \\
\text { eye defects (retinal abnormalities, late corneal opacity), } \\
\text { placental defects [149-153]. }\end{array}$ \\
\hline$R \times r b$ & NR2B2 & 98215 & $\begin{array}{l}\text { Partial embryonic and perinatal lethality, and surviving adult } \\
\text { males are sterile due to defects in spermatogenesis [154] }\end{array}$ \\
\hline Rxrg & NR2B3 & 98216 & $\begin{array}{l}\text { Neuron reduction in striatum, premature death and } \\
\text { altered responses to the administration of dopamine } \\
\text { antagonists [155] }\end{array}$ \\
\hline Stra6 & & 107742 & $\begin{array}{l}\text { Seven-fold reduction in total ocular retinoids, } \\
\text { photoreceptor anomalies, abnormal RPE, sclera, and } \\
\text { choroid [20] }\end{array}$ \\
\hline
\end{tabular}

autocrine vs. paracrine signaling, embryonic or postnatal lethality, and tissue-specific expression (or lack thereof). All of these can contribute to the discrepancies between mouse models for the RA-signaling pathway genes, observed human diseases, and the pLI scores.

\section{Future studies of the retinoic acid signaling pathway}

By means of analysis of genetic intolerance, we can pinpoint certain members of the RA-signaling pathway that are likely to be essential for human life. Clearly, it is important that these members need to be better understood. This can be achieved by generating hypomorphic mutations in mice, i.e., protein function is diminished rather than ablated. Hypomorphic mutations in mice can be studied via the introduction of single-nucleotide variants (SNVs) using CRISPR/Cas9 technology [reviewed in [167]]. This approach was recently used to study hypomorphic mutations in a humanized CYP $3 A 5 * 1$ mouse model [168]. These humanized mice with hypomorphic mutations are likely to be better models of human diseases associated with altered RA-signaling pathways.

While CRISPR/Cas9 can be effectively used for modeling human diseases in mice, such studies can be prohibitively inefficient in that they use advanced techniques, need specialized equipment, and require at least 3 months to generate knockin/knockout mice [169]. Zebrafish represent an alternative in which high-throughput screening can be used to investigate mutations in genes of the RA-signaling pathway that have been identified in humans [[170] and reviewed in [171]]. Zebrafish are more efficient than mice for such CRISPR/Cas 9 experimental approaches for several reasons: they have a shorter generation time, produce more offspring, and are less expensive to maintain [172-175]. CRISPR/Cas 9 was recently used in zebrafish to generate a humanized model of renal agenesis in which GREB1 like retinoic acid receptor coactivator (GREB1L) was identified as a coactivator of RAR genes [176]. It is expected that similar approaches will be used in future studies to manipulate the RA-signaling pathway and thereby enhance our understanding of RA-signaling in human physiology and pathophysiology.

\section{Conclusions}

For centuries, the importance of dietary vitamin A to human health has been known. Ancient civilizations unknowingly used homeopathic remedies in which vitamin A was the main active ingredient. It was not until the turn of the twentieth century that our more nuanced understanding of the role for vitamin A in human health began to take shape. Pioneering animal studies determined that vitamin A was critical for embryogenesis, eye development, and identified retinoids as derivatives of vitamin A. Decades later, our understanding of the RAsignaling pathway has grown significantly and now includes a more comprehensive knowledge of retinol cellular uptake and oxidation, RA catabolism, nuclear receptor (RAR/RXR) activation, and nuclear receptor gene targets-and the importance of the RA-signaling pathway for eye development. By leveraging information gained from large-scale human whole-exome sequencing efforts (e.g., ExAC and gnomAD), our understanding about the importance of the RA-signaling pathway to human health is improving. This was underscored by the high number of genes within this pathway with large pLI scores. While transgenic mouse models have provided valuable insights into the details of the RA pathway, discrepancies between the human and mouse data 
underscore the need for care when generalizing results from animal studies to humans.

Animal models will continue to enhance our understanding of the RA-signaling pathway under physiological and pathophysiological conditions. Exciting new models and techniques (e.g., Zebrafish, CRISPR/Cas9, hypomorphic mutations) will allow a more nuanced examination of this pathway. These will allow the pathophysiological consequences of individual human mutations in the RA-signaling pathway to be explored. In summary, the RA-signaling pathway play a critical role in embryogenesis, eye development, and are required for life. We should anticipate fascinating new insights into this pathway in the coming years.

\begin{abstract}
Abbreviations
ADH1: Alcohol dehydrogenase 1; ADH7: Alcohol dehydrogenase 7;

ALDH1A1: Aldehyde dehydrogenase 1 family member A1;

ALDH1A2: Aldehyde dehydrogenase 1 family member A2;

ALDH1A3: Aldehyde dehydrogenase 1 family member A3; ATRA: All-transretinoic acid; CRBP: Cellular retinol-binding protein; CYP26A1: Cytochrome P450 family 26 subfamily A member 1; CYP26B1: Cytochrome P450 family 26 subfamily B member 1; CYP26C1: Cytochrome P450 family 26 subfamily C member 1; DRs: Direct repeats; ExAC: Exome Aggregation Consortium; gnomAD: The Genome Aggregation Database; GREB1L: GREB1 like retinoic acid receptor coactivator; LOF: Loss of function; MAC: Microphthalmia, anophthalmia, and coloboma; pLI: Probability loss of function intolerance; POM: Periocular mesenchyme; PTVs: Protein-truncated variants; RA: Retinoic acid; RAR: Retinoic acid receptor; RARE: Retinoic acid response elements; RBP4: Retinol-binding protein 4; RDH10: Retinol dehydrogenase 10; RDH5: Retinol dehydrogenase 5; RPE: Retinal pigment epithelium; RXR: Retinoid X receptor; STRA6: Stimulated by retinoic acid 6; WES: Wholeexome sequencing
\end{abstract}

\section{Acknowledgements}

We thank the Yale Printing and Publishing Service for their assistance with Fig. 2, and also appreciate our colleagues for careful reading of this manuscript and constructive comments.

\section{Authors' contributions}

BT participated in writing and editing the manuscript and generating Tables 1 and 2 and Figs. 1 and 2. NK participated in writing and editing the manuscript and providing insightful feedback. NA participated in writing the manuscript and generating Tables 1 and 2. DCT and DWN participated in writing and editing the manuscript, and providing insightful feedback. W participated in conceiving the idea for the manuscript and in drafting, editing, and finalizing the manuscript.

\section{Funding}

This work was supported in parts by National Institutes of Health Grants AA021724, AA022057, EY017963, and EY022312. The content is solely the responsibility of the authors and does not necessarily represent the official views of the National Institutes of Health.

\section{Availability of data and materials}

All data analyzed in this review are included in this published article: Karczewski KJ, Francioli LC, Tiao G, Cummings BB, Alföldi J, Wang Q, et al. Variation across 141,456 human exomes and genomes reveals the spectrum of loss-of-function intolerance across human protein-coding genes. bioRxiv. 2019:531210; doi: https://doi.org/10.1101/531210

\section{Competing interests}

The authors declare that they have no competing interests.

\section{Author details}

Department of Environmental Health Sciences, Yale School of Public Health, 60 College St, New Haven, CT 06520, USA. ² Stanley Manne Research Institute,
Lurie Children's Hospital, Chicago, IL 60611, USA. ${ }^{3}$ Departments of Pediatrics, Northwestern University Feinberg School of Medicine, Chicago, IL 60611, USA. ${ }^{4}$ Department of Clinical Pharmacy, Skaggs School of Pharmacy and Pharmaceutical Sciences, University of Colorado Denver, Aurora, CO 80045, USA. ${ }^{5}$ Department of Environmental Health and Center for Environmental Genetics, University Cincinnati Medical Center, Cincinnati, OH 45267-0056, USA.

Received: 24 October 2019 Accepted: 12 November 2019

Published online: 03 December 2019

\section{References}

1. Mackay HM. Vitamin A deficiency in children: Part I. Present knowledge of the clinical effects of vitamin A deficiency, with special reference to children. Arch Dis Child. 1934;9(50):65-90.

2. Eusterman GB, Wilbur DL. Clinical features of vitamin A deficiency. J Amer Med Assoc. 1932;98:2054-60.

3. Wilson JG, Roth $\mathrm{CB}$, Warkany J. An analysis of the syndrome of malformations induced by maternal vitamin a deficiency. Effects of restoration of vitamin a at various times during gestation. Am J Anatomy. 1953;92(2):189-217.

4. Osborne T, LB M. The relationship of growth to the chemical constituents of the diet. J Biol Chem. 1913;15:311.

5. Wolbach SB, Howe PR. Tissue changes following deprivation of fat-soluble a vitamin. J Exp Med. 1925;42(6):753-77.

6. Semba RD. On the 'discovery' of vitamin A. Ann Nutr Metab. 2012;61 (3):192-8.

7. Lamb TD, Pugh EN Jr. Phototransduction, dark adaptation, and rhodopsin regeneration the proctor lecture. Invest Ophthalmol Vis Sci. 2006;47(12): $5138-52$.

8. White JC, Shankar VN, Highland M, Epstein ML, DeLuca HF, Clagett-Dame M. Defects in embryonic hindbrain development and fetal resorption resulting from vitamin A deficiency in the rat are prevented by feeding pharmacological levels of all-trans-retinoic acid. Proc Natl Acad Sci U S A. 1998;95(23):13459-64.

9. Benbrook DM, Chambon P, Rochette-Egly C, Asson-Batres MA. History of retinoic acid receptors. Subcell Biochem. 2014;70:1-20.

10. Sporn MB, Dunlop NM, Newton DL, Henderson WR. Relationships between Structure and Activity of Retinoids. Nature. 1976;263(5573):110-3.

11. Luca DL, Little EP, George W. Vitamin A and Protein Synthesis by Rat Intestinal Mucosa. J Biol Chem. 1969;244:701-8.

12. Sun $\mathrm{H}$, Kawaguchi $\mathrm{R}$. The membrane receptor for plasma retinol-binding protein, a new type of cell-surface receptor. Int Rev Cell Mol Biol. 2011;288: $1-41$.

13. Niederreither K, Dolle P. Retinoic acid in development: towards an integrated view. Nat Rev Genet. 2008;9(7):541-53.

14. Duester $\mathrm{G}$. Retinoic acid synthesis and signaling during early organogenesis. Cell. 2008;134(6):921-31.

15. Trumbo P, Yates AA, Schlicker S, Poos M. Dietary reference intakes: Vitamin A, Vitamin $K$, arsenic, boron, chromium, copper, iodine, iron, manganese, molybdenum, nickel, silicon, vanadium, and zinc. J Am Diet Assoc. 2001; 101(3):294-301.

16. Karczewski KJ, Francioli LC, Tiao G, Cummings BB, Alföldi J, Wang Q, et al. Variation across 141,456 human exomes and genomes reveals the spectrum of loss-of-function intolerance across human protein-coding genes. bioRxiv. 2019:531210.

17. Marill J, Idres N, Capron CC, Nguyen E, Chabot GG. Retinoic acid metabolism and mechanism of action: a review. Curr Drug Metab. 2003; $4(1): 1-10$.

18. D'Ambrosio DN, Clugston RD, Blaner WS. Vitamin A metabolism: an update. Nutrients. 2011:3(1):63-103.

19. Kawaguchi R, Yu J, Honda J, Hu J, Whitelegge J, Ping P, et al. A membrane receptor for retinol binding protein mediates cellular uptake of Vitamin $\mathrm{A}$. Science. 2007:315(5813):820.

20. Amengual J, Zhang N, Kemerer M, Maeda T, Palczewski K, Von Lintig J. STRA6 is critical for cellular vitamin A uptake and homeostasis. Hum Mol Genet. 2014;23(20):5402-17.

21. Pares X, Farres J, Kedishvili N, Duester G. Medium- and short-chain dehydrogenase/reductase gene and protein families : Medium-chain and short-chain dehydrogenases/reductases in retinoid metabolism. Cell Mol Life Sci. 2008;65(24):3936-49. 
22. Boleda MD, Saubi N, Farres J, Pares X. Physiological substrates for rat alcohol dehydrogenase classes: aldehydes of lipid peroxidation, w-hydroxyfatty acids, and retinoids. Arch Biochem Biophys. 1993;307(1):85-90.

23. Yang Z-N, Davis GJ, Hurley TD, Stone CL, Li T-K, Bosron WF. Catalytic efficiency of human alcohol dehydrogenases for retinol oxidation and retinal reduction. Alcohol Clin Exp Res. 1994;18(3):587-91.

24. Sandell LL, Sanderson BW, Moiseyev G, Johnson T, Mushegian A, Young K, et al. RDH10 is essential for synthesis of embryonic retinoic acid and is required for limb, craniofacial, and organ development. Genes Dev. 2007; 21(9):1113-24.

25. Rhinn M, Dolle P. Retinoic acid signalling during development. Development. 2012;139(5):843-58.

26. Niederreither K, McCaffery P, Drager UC, Chambon P, Dolle P. Restricted expression and retinoic acid-induced downregulation of the retinaldehyde dehydrogenase type 2 (RALDH-2) gene during mouse development. Mech Dev. 1997;62(1):67-78.

27. Matt N, Dupé V, Garnier J-M, Dennefeld C, Chambon P, Mark M, et al. Retinoic acid-dependent eye morphogenesis is orchestrated by neural crest cells. Development. 2005;132(21):4789.

28. Molotkov A, Molotkova N, Duester G. Retinoic acid guides eye morphogenetic movements via paracrine signaling but is unnecessary for retinal dorsoventral patterning. Development. 2006;133(10):1901-10.

29. Lampert JM, Holzschuh J, Hessel S, Driever W, Vogt K, von Lintig J. Provitamin A conversion to retinal via the beta,beta-carotene-15,15'oxygenase (bcox) is essential for pattern formation and differentiation during zebrafish embryogenesis. Development. 2003;130(10):2173-86.

30. Gong X, Marisiddaiah R, Rubin LP. Inhibition of pulmonary $\beta$-carotene 15, 15'-oxygenase expression by glucocorticoid involves PPARa. PloS One. 2017; 12(7):e0181466-e.

31. Uhlen M, Zhang C, Lee S, Sjöstedt E, Fagerberg L, Bidkhori G, et al. A pathology atlas of the human cancer transcriptome. Science. 2017; 357(6352):eaan2507.

32. The Human Protein Atlas [Available from: http://www.proteinatlas.org]. Accessed 6 Sept 2019.

33. Duh EJ, Yang HS, Suzuma I, Miyagi M, Youngman E, Mori K, et al. Pigment epithelium-derived factor suppresses ischemia-induced retinal neovascularization and VEGF-induced migration and growth. Invest Ophthalmol Vis Sci. 2002;43(3):821-9.

34. Wang XD, Russell RM, Liu C, Stickel F, Smith DE, Krinsky NI. Beta-oxidation in rabbit liver in vitro and in the perfused ferret liver contributes to retinoic acid biosynthesis from beta-apocarotenoic acids. J Biol Chem. 1996;271(43):26490-8.

35. Chambers D, Wilson L, Maden M, Lumsden A. RALDH-independent generation of retinoic acid during vertebrate embryogenesis by CYP1B1. Development. 2007;134(7):1369-83

36. Collins MD, Mao GE. Teratology of Retinoids. Ann Rev Pharmacol Toxicol. 1999;39(1):399-430.

37. Chithalen JV, Luu L, Petkovich M, Jones G. HPLC-MS/MS analysis of the products generated from all-trans-retinoic acid using recombinant human CYP26A. J Lipid Res. 2002;43(7):1133-42.

38. MacLean G, Abu-Abed S, Dolle P, Tahayato A, Chambon P, Petkovich M. Cloning of a novel retinoic-acid metabolizing cytochrome P450, Cyp26B1, and comparative expression analysis with Cyp26A1 during early murine development. Mech Dev. 2001;107(1-2):195-201.

39. Tahayato A, Dolle P, Petkovich M. Cyp26C1 encodes a novel retinoic acidmetabolizing enzyme expressed in the hindbrain, inner ear, first branchial arch and tooth buds during murine development. Gene Expr Patterns. 2003; 3(4):449-54

40. Nebert DW, Wikvall K, Miller WL. Human cytochromes P450 in health and disease. Philos Trans R Soc Lond B Biol Sci. 2013;368(1612):20120431.

41. Pijnappel WW, Hendriks HF, Folkers GE, van den Brink CE, Dekker EJ, Edelenbosch C, et al. The retinoid ligand 4-oxo-retinoic acid is a highly active modulator of positional specification. Nature. 1993:366(6453):340-4.

42. Niederreither K, Abu-Abed S, Schuhbaur B, Petkovich M, Chambon P, Dolle P. Genetic evidence that oxidative derivatives of retinoic acid are not involved in retinoid signaling during mouse development. Nat Genet. 2002;31(1):84-8.

43. Rochette-Egly C, Germain P. Dynamic and combinatorial control of gene expression by nuclear retinoic acid receptors (RARs). Nucl Recept Signal. 2009;7:e005

44. Mic FA, Molotkov A, Benbrook DM, Duester G. Retinoid activation of retinoic acid receptor but not retinoid $X$ receptor is sufficient to rescue lethal defect in retinoic acid synthesis. Proc Natl Acad Sci U S A. 2003;100(12):7135-40.
45. Chawla A, Repa JJ, Evans RM, Mangelsdorf DJ. Nuclear receptors and lipid physiology: opening the X-files. Science. 2001;294(5548):1866-70.

46. Roy B, Taneja R, Chambon P. Synergistic activation of retinoic acid (RA)responsive genes and induction of embryonal carcinoma cell differentiation by an RA receptor alpha (RAR alpha)-, RAR beta-, or RAR gamma-selective ligand in combination with a retinoid $\mathrm{X}$ receptor-specific ligand. Mol Cell Biol. 1995;15(12):6481-7.

47. Dolle P. Developmental expression of retinoic acid receptors (RARs). Nucl Recept Signal. 2009;7:e006

48. Perlmann T, Rangarajan PN, Umesono K, Evans RM. Determinants for selective RAR and TR recognition of direct repeat HREs. Genes Dev. 1993; 7(7b):1411-22.

49. Mader S, Leroy P, Chen JY, Chambon P. Multiple parameters control the selectivity of nuclear receptors for their response elements. Selectivity and promiscuity in response element recognition by retinoic acid receptors and retinoid X receptors. J Biol Chem. 1993;268(1):591-600.

50. Kurokawa R, Söderström M, Hörlein A, Halachmi S, Brown M, Rosenfeld MG, et al. Polarity-specific activities of retinoic acid receptors determined by a co-repressor. Nature. 1995:377(6548):451-4.

51. Balmer JE, Blomhoff R. Gene expression regulation by retinoic acid. J Lipid Res. 2002;43(11):1773-808.

52. Savory JG, Edey C, Hess B, Mears AJ, Lohnes D. Identification of novel retinoic acid target genes. Dev Biol. 2014;395(2):199-208.

53. Luijten $M$, van Beelen VA, Verhoef $A$, Renkens MF, van Herwijnen $M H$, Westerman A, et al. Transcriptomics analysis of retinoic acid embryotoxicity in rat postimplantation whole embryo culture. Reprod Toxicol. 2010;30(2): 333-40.

54. Cvekl A, Wang W-L. Retinoic acid signaling in mammalian eye development. Exp Eye Res. 2009;89(3):280-91

55. Richardson R, Tracey-White D, Webster A, Moosajee M. The zebrafish eye-a paradigm for investigating human ocular genetics. Eye (Lond). 2017;31(1): 68-86.

56. Van Cruchten S, Vrolyk V, Perron Lepage M-F, Baudon M, Voute H, Schoofs $\mathrm{S}$, et al. Pre- and postnatal development of the eye: a species comparison. Birth Defects Res. 2017;109(19):1540-67.

57. Kaufmann P. The anatomical basis of mouse development. J Anat. 2000; 197(Pt 2):331-2.

58. Chow RL, Lang RA. Early eye development in vertebrates. Ann Rev Cell Dev Biol. 2001;17(1):255-96.

59. Cvekl A, Ashery-Padan R. The cellular and molecular mechanisms of vertebrate lens development. Development. 2014;141(23):4432.

60. Mui SH, Kim JW, Lemke G, Bertuzzi S. Vax genes ventralize the embryonic eye. Genes Dev. 2005;19(10):1249-59.

61. Schmitt EA, Dowling JE. Early-eye morphogenesis in the zebrafish, Brachydanio rerio. J Comp Neurol. 1994;344(4):532-42.

62. Warkany J, Schraffenberger E. Congenital malformations induced in rats by maternal vitamin a deficiency: I. Defects of the Eye. JAMA Ophthalmol. 1946, 35(2):150-69.

63. Isken A, Golczak M, Oberhauser V, Hunzelmann S, Driever W, Imanishi Y, et al. RBP4 disrupts vitamin A uptake homeostasis in a STRA6-deficient animal model for Matthew-Wood syndrome. Cell Metabol. 2008;7(3):258-68.

64. D'Aniello E, Ravisankar P, Waxman JS. Rdh10a provides a conserved critical step in the synthesis of retinoic acid during zebrafish embryogenesis. Plos One. 2015;10(9):e0138588-e.

65. Mic FA, Molotkov A, Molotkova N, Duester G. Raldh2 expression in optic vesicle generates a retinoic acid signal needed for invagination of retina during optic cup formation. Dev Dyn. 2004:231(2):270-7.

66. Dupe V, Matt N, Garnier JM, Chambon P, Mark M, Ghyselinck NB. A newborn lethal defect due to inactivation of retinaldehyde dehydrogenase type 3 is prevented by maternal retinoic acid treatment. Proc Natl Acad Sci U S A. 2003:100(24):14036-41.

67. Bohnsack BL, Kasprick DS, Kish PE, Goldman D, Kahana A. A Zebrafish model of axenfeld-rieger syndrome reveals that pitx2 regulation by Retinoic acid is essential for ocular and craniofacial development. Invest Ophthalmol Vis Sci. 2012;53(1):7-22.

68. Matt N, Ghyselinck NB, Pellerin I, Dupé V. Impairing retinoic acid signalling in the neural crest cells is sufficient to alter entire eye morphogenesis. Dev Biol. 2008;320(1):140-8.

69. Perez-Castro AV, Tran VT, Nguyen-Huu MC. Defective lens fiber differentiation and pancreatic tumorigenesis caused by ectopic expression of the cellular retinoic acid-binding protein I. Development. 1993;119(2):363. 
70. Lohnes D, Mark M, Mendelsohn C, Dolle P, Dierich A, Gorry P, et al. Function of the retinoic acid receptors (RARs) during development (I). Craniofacial and skeletal abnormalities in RAR double mutants. Development. 1994; 120(10):2723.

71. Grondona JM, Kastner P, Gansmuller A, Decimo D, Chambon P, Mark M. Retinal dysplasia and degeneration in RARbeta2/RARgamma2 compound mutant mice. Development. 1996;122(7):2173.

72. Kastner P, Grondona JM, Mark M, Gansmuller A, LeMeur M, Decimo D, et al. Genetic analysis of RXRa developmental function: Convergence of RXR and RAR signaling pathways in heart and eye morphogenesis. Cell. 1994;78(6): 987-1003.

73. Chou CM, Nelson C, Tarle SA, Pribila JT, Bardakjian T, Woods S, et al. Biochemical basis for dominant inheritance, variable penetrance, and maternal effects in RBP4 congenital eye disease. Cell. 2015;161(3):634-46.

74. Riera M, Wert A, Nieto I, Pomares E. Panel-based whole exome sequencing identifies novel mutations in microphthalmia and anophthalmia patients showing complex Mendelian inheritance patterns. Mol Genet Genomic Med. 2017;5(6):709-19.

75. Casey J, Kawaguchi R, Morrissey M, Sun H, McGettigan P, Nielsen JE, et al. First implication of STRA6 mutations in isolated anophthalmia, microphthalmia, and coloboma: a new dimension to the STRA6 phenotype. Hum Mutat. 2011;32(12):1417-26.

76. Chitayat D, Sroka H, Keating S, Colby RS, Ryan G, Toi A, et al. The PDAC syndrome (pulmonary hypoplasia/agenesis, diaphragmatic hernia/ eventration, anophthalmia/microphthalmia, and cardiac defect) (Spear syndrome, Matthew-Wood syndrome): Report of eight cases including a living child and further evidence for autosomal recessive inheritance. Am J Med Genet A. 2007;143A(12):1268-81.

77. Golzio C, Martinovic-Bouriel J, Thomas S, Mougou-Zrelli S, GrattaglianoBessieres B, Bonniere M, et al. Matthew-Wood syndrome is caused by truncating mutations in the retinol-binding protein receptor gene STRA6. Am J Hum Genet. 2007;80(6):1179-87.

78. Pasutto F, Flinter F, Rauch A, Reis A. Novel STRA6 null mutations in the original family described with Matthew-Wood syndrome. Am J Med Genet A. 2018;176(1):134-8.

79. Fares-Taie L, Gerber S, Chassaing N, Clayton-Smith J, Hanein S, Silva E, et al. ALDH1A3 mutations cause recessive anophthalmia and microphthalmia. Am J Hum Genet. 2013;92(2):265-70.

80. Yahyavi M, Abouzeid H, Gawdat G, de Preux AS, Xiao T, Bardakjian T, et al. ALDH1A3 loss of function causes bilateral anophthalmia/microphthalmia and hypoplasia of the optic nerve and optic chiasm. Hum Mol Genet. 2013; 22(16):3250-8.

81. Mory A, Ruiz FX, Dagan E, Yakovtseva EA, Kurolap A, Parés X, et al. A missense mutation in ALDH1A3 causes isolated microphthalmia/ anophthalmia in nine individuals from an inbred Muslim kindred. Eur J Hum Genet. 2013;22:419.

82. Srour M, Chitayat D, Caron V, Chassaing N, Bitoun P, Patry L, et al. Recessive and dominant mutations in retinoic acid receptor beta in cases with microphthalmia and diaphragmatic hernia. Am J Hum Genet. 2013;93(4):765-72.

83. Nobile S, Pisaneschi E, Novelli A, Carnielli VP. A rare mutation of retinoic acid receptor- $\beta$ associated with lethal neonatal Matthew-Wood syndrome. Clin Dysmorphol. 2019;28(2):74-7.

84. Jakubiuk-Tomaszuk A, Murcia Pienkowski V, Zietkiewicz S, Rydzanicz M, Kosińska J, Stawiński P, et al. Syndromic chorioretinal coloboma associated with heterozygous de novo RARA mutation affecting an amino acid critical for retinoic acid interaction. Clin Genet. 2019;0(0)

85. Lek M, Karczewski KJ, Minikel EV, Samocha KE, Banks E, Fennell T, et al. Analysis of protein-coding genetic variation in 60,706 humans. Nature. 2016; 536(7616):285-91.

86. Streissguth AP, Dehaene P. Fetal alcohol syndrome in twins of alcoholic mothers: concordance of diagnosis and IQ. Am J Med Genet. 1993;47(6) 857-61.

87. Stamatoyannopoulos G, Chen SH, Fukui M. Liver alcohol dehydrogenase in Japanese: high population frequency of atypical form and its possible role in alcohol sensitivity. Am J Hum Genet. 1975;27(6):789-96.

88. Takeshita T, Mao XQ, Morimoto K. The contribution of polymorphism in the alcohol dehydrogenase beta subunit to alcohol sensitivity in a Japanese population. Hum Genet. 1996;97(4):409-13.

89. Eckey R, Agarwal DP, Saha N, Goedde HW. Detection and partial characterization of a variant form of cytosolic aldehyde dehydrogenase isozyme. Hum Genet. 1986;72(1):95-7.
90. Yoshida A, Dave V, Ward RJ, Peters TJ. Cytosolic aldehyde dehydrogenase (ALDH1) variants found in alcohol flushers. Ann Hum Genet. 1989:53(Pt 1):1-7.

91. Stoilov I, Akarsu AN, Sarfarazi M. Identification of three different truncating mutations in cytochrome P4501B1 (CYP1B1) as the principal cause of primary congenital glaucoma (Buphthalmos) in families linked to the GLC3A locus on chromosome 2p21. Hum Mol Genet. 1997:6(4):641-7.

92. Stoilov I, Akarsu AN, Alozie I, Child A, Barsoum-Homsy M, Turacli ME, et al. Sequence analysis and homology modeling suggest that primary congenital glaucoma on 2 p21 results from mutations disrupting either the hinge region or the conserved core structures of cytochrome P4501B1. Am J Hum Genet. 1998;62(3):573-84.

93. Melki R, Colomb E, Lefort N, Brezin AP, Garchon HJ. CYP1B1 mutations in French patients with early-onset primary open-angle glaucoma. J Med Genet. 2004;41(9):647-51.

94. Vincent A, Billingsley G, Priston M, Williams-Lyn D, Sutherland J, Glaser T, et al. Phenotypic heterogeneity of CYP1B1: mutations in a patient with Peters' anomaly. J Med Genet. 2001:38(5):324-6.

95. Lee SJ, Perera L, Coulter SJ, Mohrenweiser HW, Jetten A, Goldstein JA. The discovery of new coding alleles of human CYP26A1 that are potentially defective in the metabolism of all-trans retinoic acid and their assessment in a recombinant cDNA expression system. Pharmacogenet Genomics. 2007; 17(3):169-80.

96. Laue K, Pogoda HM, Daniel PB, van Haeringen A, Alanay Y, von Ameln S, et al. Craniosynostosis and multiple skeletal anomalies in humans and zebrafish result from a defect in the localized degradation of retinoic acid. Am J Hum Genet. 2011;89(5):595-606.

97. Slavotinek AM, Mehrotra P, Nazarenko I, Tang PL, Lao R, Cameron D, et al. Focal facial dermal dysplasia, type IV, is caused by mutations in CYP26C1. Hum Mol Genet. 2013;22(4):696-703.

98. Guidez F, Parks S, Wong H, Jovanovic JV, Mays A, Gilkes AF, et al. RARalphaPLZF overcomes PLZF-mediated repression of CRABPI, contributing to retinoid resistance in $\mathrm{t}(11 ; 17)$ acute promyelocytic leukemia. Proc Natl Acad Sci U S A. 2007;104(47):18694-9.

99. Madsen P, Rasmussen HH, Leffers H, Honore B, Celis JE. Molecular cloning and expression of a novel keratinocyte protein (psoriasis-associated fatty acid-binding protein [PA-FABP]) that is highly up-regulated in psoriatic skin and that shares similarity to fatty acid-binding proteins. J Invest Dermatol. 1992;99(3):299-305.

100. Borrow J, Goddard AD, Sheer D, Solomon E. Molecular analysis of acute promyelocytic leukemia breakpoint cluster region on chromosome 17. Science. 1990;249(4976):1577-80.

101. Such E, Cervera J, Valencia A, Barragan E, Ibanez M, Luna I, et al. A novel NUP98/RARG gene fusion in acute myeloid leukemia resembling acute promyelocytic leukemia. Blood. 2011;117(1):242-5.

102. Seeliger MW, Biesalski HK, Wissinger B, Gollnick H, Gielen S, Frank J, et al. Phenotype in retinol deficiency due to a hereditary defect in retinol binding protein synthesis. Invest Ophthalmol Vis Sci. 1999:40(1):3-11.

103. Yamamoto H, Simon A, Eriksson U, Harris E, Berson EL, Dryja TP. Mutations in the gene encoding 11-cis retinol dehydrogenase cause delayed dark adaptation and fundus albipunctatus. Nat Genet. 1999;22(2):188-91.

104. Gonzalez-Fernandez F, Kurz D, Bao Y, Newman S, Conway BP, Young JE, et al. 11-cis retinol dehydrogenase mutations as a major cause of the congenital night-blindness disorder known as fundus albipunctatus. Mol Vis. 1999;5:41.

105. Deltour L, Foglio MH, Duester G. Metabolic deficiencies in alcohol dehydrogenase Adh1, Adh3, and Adh4 null mutant mice. Overlapping roles of Adh1 and Adh4 in ethanol clearance and metabolism of retinol to retinoic acid. J Biol Chem. 1999;274(24):16796-801.

106. Molotkov A, Deltour L, Foglio MH, Cuenca AE, Duester G. Distinct retinoid metabolic functions for alcohol dehydrogenase genes Adh1 and Adh4 in protection against vitamin A toxicity or deficiency revealed in double null mutant mice. J Biol Chem. 2002;277(16):13804-11.

107. Molotkov A, Fan X, Duester G. Excessive vitamin A toxicity in mice genetically deficient in either alcohol dehydrogenase Adh1 or Adh3. Eur $J$ Biochem. 2002;269(10):2607-12.

108. Ziouzenkova O, Orasanu G, Sharlach M, Akiyama TE, Berger JP, Viereck J, et al. Retinaldehyde represses adipogenesis and diet-induced obesity. Nat Med. 2007;13(6):695-702.

109. Fan X, Molotkov A, Manabe S, Donmoyer CM, Deltour L, Foglio MH, et al. Targeted disruption of Aldh1a1 (Raldh1) provides evidence for a complex mechanism of retinoic acid synthesis in the developing retina. Mol Cell Biol. 2003;23(13):4637-48 
110. Niederreither K, Subbarayan V, Dolle P, Chambon P. Embryonic retinoic acid synthesis is essential for early mouse post-implantation development. Nat Genet. 1999;21(4):444-8.

111. Niederreither K, Vermot J, Schuhbaur B, Chambon P, Dolle P. Retinoic acid synthesis and hindbrain patterning in the mouse embryo. Development. 2000;127(1):75-85.

112. Mic FA, Haselbeck RJ, Cuenca AE, Duester G. Novel retinoic acid generating activities in the neural tube and heart identified by conditional rescue of Raldh2 null mutant mice. Development. 2002;129(9):2271-82.

113. Ribes V, Wang Z, Dolle P, Niederreither K. Retinaldehyde dehydrogenase 2 (RALDH2)-mediated retinoic acid synthesis regulates early mouse embryonic forebrain development by controlling FGF and sonic hedgehog signaling. Development. 2006;133(2):351-61.

114. Vermot J, Niederreither K, Garnier JM, Chambon P, Dolle P. Decreased embryonic retinoic acid synthesis results in a DiGeorge syndrome phenotype in newborn mice. Proc Natl Acad Sci U S A. 2003;100(4):1763-8.

115. Molotkova N, Molotkov A, Duester G. Role of retinoic acid during forebrain development begins late when Raldh3 generates retinoic acid in the ventral subventricular zone. Dev Biol. 2007:303(2):601-10.

116. Singh S, Chen Y, Matsumoto A, Orlicky DJ, Dong H, Thompson DC, et al. ALDH1B1 links alcohol consumption and diabetes. Biochem Biophys Res Commun. 2015;463(4):768-73.

117. Anastasiou V, Ninou E, Alexopoulou D, Stertmann J, Muller A, Dahl A, et al. Aldehyde dehydrogenase activity is necessary for beta cell development and functionality in mice. Diabetologia. 2016;59(1):139-50.

118. Heidel SM, MacWilliams PS, Baird WM, Dashwood WM, Buters JT, Gonzalez FJ, et al. Cytochrome P4501B1 mediates induction of bone marrow cytotoxicity and preleukemia cells in mice treated with 7,12dimethylbenz[a]anthracene. Cancer Res. 2000;60(13):3454-60.

119. Buters JT, Sakai S, Richter T, Pineau T, Alexander DL, Savas U, et al. Cytochrome P450 CYP1B1 determines susceptibility to 7, 12dimethylbenz[a]anthracene-induced lymphomas. Proc Natl Acad Sci U S A 1999;96(5):1977-82.

120. Libby RT, Smith RS, Savinova OV, Zabaleta A, Martin JE, Gonzalez FJ, et al. Modification of ocular defects in mouse developmental glaucoma models by tyrosinase. Science. 2003;299(5612):1578-81.

121. Abu-Abed S, Dolle P, Metzger D, Beckett B, Chambon P, Petkovich M. The retinoic acid-metabolizing enzyme, CYP26A1, is essential for normal hindbrain patterning, vertebral identity, and development of posterior structures. Genes Dev. 2001;15(2):226-40.

122. Sakai $Y$, Meno C, Fujii H, Nishino J, Shiratori $H$, Saijoh $Y$, et al. The retinoic acid-inactivating enzyme CYP26 is essential for establishing an uneven distribution of retinoic acid along the anterio-posterior axis within the mouse embryo. Genes Dev. 2001;15(2):213-25.

123. Yashiro K, Zhao X, Uehara M, Yamashita K, Nishijima M, Nishino J, et al. Regulation of retinoic acid distribution is required for proximodistal patterning and outgrowth of the developing mouse limb. Dev Cell. 2004; 6(3):411-22.

124. MacLean G, Li H, Metzger D, Chambon P, Petkovich M. Apoptotic extinction of germ cells in testes of Cyp26b1 knockout mice. Endocrinology. 2007; 148(10):4560-7.

125. Li H, MacLean G, Cameron D, Clagett-Dame M, Petkovich M. Cyp26b1 expression in murine Sertoli cells is required to maintain male germ cells in an undifferentiated state during embryogenesis. PLoS One. 2009;4(10):e7501.

126. Okano J, Lichti U, Mamiya S, Aronova M, Zhang G, Yuspa SH, et al. Increased retinoic acid levels through ablation of Cyp26b1 determine the processes of embryonic skin barrier formation and peridermal development. J Cell Sci. 2012:125(Pt 7):1827-36.

127. Uehara M, Yashiro K, Mamiya S, Nishino J, Chambon P, Dolle P, et al. CYP26A1 and CYP26C1 cooperatively regulate anterior-posterior patterning of the developing brain and the production of migratory cranial neural crest cells in the mouse. Dev Biol. 2007:302(2):399-411.

128. Gorry P, Lufkin T, Dierich A, Rochette-Egly C, Decimo D, Dolle P, et al. The cellular retinoic acid binding protein I is dispensable. Proc Natl Acad Sci U S A. 1994;91(19):9032-6.

129. Fawcett D, Pasceri $P$, Fraser $R$, Colbert M, Rossant J, Giquere V. Postaxial polydactyly in forelimbs of CRABP-II mutant mice. Development. 1995; 121(3):671-9.

130. Owada Y, Takano H, Yamanaka H, Kobayashi H, Sugitani Y, Tomioka Y, et al. Altered water barrier function in epidermal-type fatty acid binding proteindeficient mice. J Invest Dermatol. 2002;118(3):430-5.
131. Maeda K, Uysal KT, Makowski L, Gorgun CZ, Atsumi G, Parker RA, et al. Role of the fatty acid binding protein mal1 in obesity and insulin resistance. Diabetes. 2003;52(2):300-7.

132. Pan Y, Short JL, Choy KH, Zeng AX, Marriott PJ, Owada Y, et al. Fatty acidbinding protein 5 at the blood-brain barrier regulates endogenous brain docosahexaenoic acid levels and cognitive function. J Neurosci. 2016;36(46): 11755-67.

133. Yu S, Levi L, Casadesus G, Kunos G, Noy N. Fatty acid-binding protein 5 (FABP5) regulates cognitive function both by decreasing anandamide levels and by activating the nuclear receptor peroxisome proliferator-activated receptor beta/delta (PPARbeta/delta) in the brain. J Biol Chem. 2014;289(18): 12748-58.

134. Chapellier B, Mark M, Garnier JM, LeMeur M, Chambon P, Ghyselinck NB. A conditional floxed (loxp-flanked) allele for the retinoic acid receptor alpha (RARalpha) gene. Genesis. 2002;32(2):87-90.

135. Ghyselinck NB, Dupe V, Dierich A, Messaddeq N, Garnier JM, Rochette-Egly $C$, et al. Role of the retinoic acid receptor beta (RARbeta) during mouse development. Int J Dev Biol. 1997;41(3):425-47.

136. Lufkin T, Lohnes D, Mark M, Dierich A, Gorry P, Gaub MP, et al. High postnatal lethality and testis degeneration in retinoic acid receptor alpha mutant mice. Proc Natl Acad Sci U S A. 1993:90(15):7225-9.

137. Mendelsohn C, Mark M, Dolle P, Dierich A, Gaub MP, Krust A, et al. Retinoic acid receptor beta 2 (RAR beta 2) null mutant mice appear normal. Dev Biol. 1994;166(1):246-58

138. Krezel W, Ghyselinck N, Samad TA, Dupe V, Kastner P, Borrelli E, et al. Impaired locomotion and dopamine signaling in retinoid receptor mutant mice. Science. 1998;279(5352):863-7.

139. Lohnes D, Kastner $P$, Dierich A, Mark M, LeMeur $M$, Chambon P. Function of retinoic acid receptor gamma in the mouse. Cell. 1993;73(4):643-58.

140. Walkley CR, Olsen GH, Dworkin S, Fabb SA, Swann J, McArthur GA, et al. A microenvironment-induced myeloproliferative syndrome caused by retinoic acid receptor gamma deficiency. Cell. 2007:129(6):1097-110.

141. Zizola CF, Frey SK, Jitngarmkusol S, Kadereit B, Yan N, Vogel S. Cellular retinol-binding protein type I (CRBP-I) regulates adipogenesis. Mol Cell Biol. 2010;30(14):3412-20.

142. Kane MA, Folias AE, Pingitore A, Perri M, Krois CR, Ryu JY, et al. Crbpl modulates glucose homeostasis and pancreas 9-cis-retinoic acid concentrations. Mol Cell Biol. 2011:31(16):3277-85.

143. Ghyselinck NB, Bavik C, Sapin V, Mark M, Bonnier D, Hindelang C, et al. Cellular retinol-binding protein I is essential for vitamin A homeostasis. EMBO J. 1999;18(18):4903-14

144. E X, Zhang L, Lu J, Tso P, Blaner WS, Levin MS, et al. Increased neonatal mortality in mice lacking cellular retinol-binding protein II. J Biol Chem. 2002;277(39):36617-23.

145. Quadro L, Blaner WS, Hamberger L, Van Gelder RN, Vogel S, Piantedosi R, et al. Muscle expression of human retinol-binding protein (RBP). Suppression of the visual defect of RBP knockout mice. J Biol Chem. 2002 277(33):30191-7.

146. Yang Q, Graham TE, Mody N, Preitner F, Peroni OD, Zabolotny JM, et al. Serum retinol binding protein 4 contributes to insulin resistance in obesity and type 2 diabetes. Nature. 2005:436(7049):356-62.

147. Driessen CA, Winkens HJ, Hoffmann K, Kuhlmann LD, Janssen BP, Van Vugt $\mathrm{AH}$, et al. Disruption of the 11-cis-retinol dehydrogenase gene leads to accumulation of cis-retinols and cis-retinyl esters. Mol Cell Biol. 2000;20(12): 4275-87.

148. Arregi I, Climent M, lliev D, Strasser J, Gouignard N, Johansson JK, et al. Retinol Dehydrogenase-10 regulates pancreas organogenesis and endocrine cell differentiation via paracrine retinoic acid signaling. Endocrinology. 2016; 157(12):4615-31.

149. Dyson E, Sucov HM, Kubalak SW, Schmid-Schonbein GW, DeLano FA, Evans RM, et al. Atrial-like phenotype is associated with embryonic ventricular failure in retinoid X receptor alpha -/- mice. Proc Natl Acad Sci U S A. 1995; 92(16):7386-90.

150. Mascrez B, Ghyselinck NB, Chambon P, Mark M. A transcriptionally silent RXRalpha supports early embryonic morphogenesis and heart development Proc Natl Acad Sci U S A. 2009;106(11):4272-7.

151. Sucov HM, Dyson E, Gumeringer CL, Price J, Chien KR, Evans RM. RXR alpha mutant mice establish a genetic basis for vitamin A signaling in heart morphogenesis. Genes Dev. 1994;8(9):1007-18.

152. Gruber PJ, Kubalak SW Pexieder T, Sucov HM, Evans RM, Chien KR. RXR alpha deficiency confers genetic susceptibility for aortic sac, conotruncal, 
atrioventricular cushion, and ventricular muscle defects in mice. J Clin Invest. 1996;98(6):1332-43.

153. Du X, Tabeta K, Mann N, Crozat K, Mudd S, Beutler B. An essential role for Rxr alpha in the development of Th2 responses. Eur J Immunol. 2005;35(12): 3414-23.

154. Kastner P, Mark M, Leid M, Gansmuller A, Chin W, Grondona JM, et al. Abnormal spermatogenesis in RXR beta mutant mice. Genes Dev. 1996; 10(1):80-92.

155. Saga Y, Kobayashi M, Ohta H, Murai N, Nakai N, Oshima M, et al. Impaired extrapyramidal function caused by the targeted disruption of retinoid $X$ receptor RXRgamma1 isoform. Genes Cells. 1999:4(4):219-28.

156. Kabir M, Barradas A, Tzotzos GT, Hentges KE, Doig AJ. Properties of genes essential for mouse development. PLoS One. 2017;12(5):e0178273.

157. Dickerson JE, Zhu A, Robertson DL, Hentges KE. Defining the role of essential genes in human disease. PLoS One. 2011;6(11):e27368.

158. Fuller ZL, Berg JJ, Mostafavi H, Sella G, Przeworski M. Measuring intolerance to mutation in human genetics. Nat Genet. 2019:51(5):772-6.

159. Jackson B, Brocker C, Thompson DC, Black W, Vasiliou K, Nebert DW, et al. Update on the aldehyde dehydrogenase gene (ALDH) superfamily. Hum Genomics. 2011;5(4):283-303.

160. Ray WJ, Bain G, Yao M, Gottlieb DI. CYP26, a novel mammalian cytochrome P450, is induced by retinoic acid and defines a new family. J Biol Chem. 1997;272(30):18702-8.

161. Topletz AR, Thatcher JE, Zelter A, Lutz JD, Tay S, Nelson WL, et al. Comparison of the function and expression of CYP26A1 and CYP26B1, the two retinoic acid hydroxylases. Biochem Pharmacol. 2012;83(1):149-63.

162. Stoney PN, Fragoso YD, Saeed RB, Ashton A, Goodman T, Simons C, et al. Expression of the retinoic acid catabolic enzyme CYP26B1 in the human brain to maintain signaling homeostasis. Brain Struct Funct. 2016;221(6): 3315-26.

163. Shawky R. Reduced penetrance in human inherited disease. Egypt J Med Hum Genet. 2014;15(2):103-11.

164. Niakan KK, Eggan K. Analysis of human embryos from zygote to blastocyst reveals distinct gene expression patterns relative to the mouse. Dev Biol. 2013:375(1):54-64.

165. Madissoon E, Tohonen V, Vesterlund L, Katayama S, Unneberg P, Inzunza J, et al. Differences in gene expression between mouse and human for dynamically regulated genes in early embryo. PLoS One. 2014;9(8):e102949.

166. Chavez SL, McElroy SL, Bossert NL, De Jonge CJ, Rodriguez MV, Leong DE, et al. Comparison of epigenetic mediator expression and function in mouse and human embryonic blastomeres. Hum Mol Genet. 2014;23(18):4970-84.

167. Birling MC, Herault Y, Pavlovic G. Modeling human disease in rodents by CRISPR/Cas9 genome editing. Mamm Genome. 2017;28(7-8):291-301.

168. Abe S, Kobayashi K, Oji A, Sakuma T, Kazuki K, Takehara S, et al. Modification of single-nucleotide polymorphism in a fully humanized CYP3A mouse by genome editing technology. Sci Rep. 2017;7(1):15189.

169. Hall B, Cho A, Limaye A, Cho K, Khillan J, Kulkarni AB. Genome Editing in Mice Using CRISPR/Cas9 Technology. Curr Protoc Cell Biol. 2018:81(1):e57.

170. Varshney GK, Carrington B, Pei W, Bishop K, Chen Z, Fan C, et al. A highthroughput functional genomics workflow based on CRISPR/Cas9-mediated targeted mutagenesis in zebrafish. Nat Protoc. 2016;11(12):2357-75.

171. Liu J, Zhou Y, Qi X, Chen J, Chen W, Qiu G, et al. CRISPR/Cas9 in zebrafish: an efficient combination for human genetic diseases modeling. Hum Genet. 2017;136(1):1-12.

172. Dooley K, Zon LI. Zebrafish: a model system for the study of human disease. Curr Opin Genet Dev. 2000;10(3):252-6.

173. Westefield M. A guide for the laboratory use of zebrafish (Danio rerio). 5th ed. Eugene: Univ. of Oregon Press; 2007.

174. Lawrence C, Adatto I, Best J, James A, Maloney K. Generation time of zebrafish (Danio rerio) and medakas (Oryzias latipes) housed in the same aquaculture facility. Lab Animal. 2012:41(6):158-65.

175. Kim S, Carlson R, Zafreen L, Rajpurohit SK, Jagadeeswaran P. Modular, easyto-assemble, low-cost zebrafish facility. Zebrafish. 2009;6(3):269-74.

176. Brophy PD, Rasmussen M, Parida M, Bonde G, Darbro BW, Hong X, et al. A gene implicated in activation of retinoic acid receptor targets is a novel renal agenesis gene in humans. Genetics. 2017;207(1):215-28.

\section{Publisher's Note}

Springer Nature remains neutral with regard to jurisdictional claims in published maps and institutional affiliations.

Ready to submit your research? Choose BMC and benefit from:

- fast, convenient online submission

- thorough peer review by experienced researchers in your field

- rapid publication on acceptance

- support for research data, including large and complex data types

- gold Open Access which fosters wider collaboration and increased citations

- maximum visibility for your research: over $100 \mathrm{M}$ website views per year

At $\mathrm{BMC}$, research is always in progress.

Learn more biomedcentral.com/submissions 